\title{
A Healthy Forest Is A Productive Forest - A Physiological Viewpoint
}

\author{
by Rod Savidge'
}

A healthy tree is a productive tree. On the other hand, a production treeone grown purely for fibre productionis not necessarily healthy, nor are stands and forests consisting of production trees.

At most times in its life, a healthy tree is able to allocate surplus reserves to root, shoot and diameter growth; however, survival and reproduction take priority over growth. Forestry everywhere on earth has been intent on 'bending' the tree's physiological priorities toward growth. Thus, whether it be licensed Crown land, private woodlot, or provincial reserve, we in Canada haven't managed for, nor have we produced - other than perhaps by accident - healthy forests.

Our fledgling nation grew primarily because there were healthy large-diameter old-growth forests, not just dense pulpmill forests, present all across our land. Ironically, today's promulgators of "sustainable forest management", "model forests," and the National Forest Strategy "action framework" have production forests rather than healthy forests as the no. 1 priority. The overriding concern is not "What can we do to make the trees and forests healthier?", rather "What can we do to the trees and forests to make us healthier?" None of Canada's research programmes into tree improvement, reforestation, silviculture or harvesting seems to have the sustainment of healthy trees, healthy populations of trees, and healthy forests as their raison d'étre, rather sustainable productivity. The trees seem to be regarded as merely overgrown vegetables, a commodity to be produced, harvested, processed and consumed. Our modus operandi seems to be jobs and human greed, not empathy for forest organisms or reverence for life. Foresters may accuse others of not being able to see the forest for the trees, but it seems that foresters cannot see the trees for the wood.

\footnotetext{
${ }^{1}$ Professor, Faculty of Forestry and Environmental Management, University of New Brunswick, Fredericton, $N B$.
}

Canada's society of registered "production" foresters has ignored the intuitively obvious - that if improved tree health is our first priority, the productivity will take care of itself.

\section{Auld lang syne}

Our old growth forests have been systematically destroyed, and every inducement still exists for the forester to think $\mathrm{s} /$ he must be acting in the best interests of the forest by seeing this destruction to completion. For example, the Minister of Forests for British Columbia recently stated: "We are overcutting what is the long-term sustainable yield, but if we don't... a lot of this would become more decadent, it would fall down and wouldn't be utilized"' (29 July 1997: CBC Evening News). Everyone has an idea what an unhealthy tree looks like after its decline has become obvious; however, we in forestry lack adequate early warning indicators of impending health problems. When I last slept beneath the undisturbed Douglas fir, Sitka spruce, western red cedar, and western hemlock of the Bella Coola, Klina Klini and Dean River valleys, most were $2 \mathrm{~m}$ and some even $4 \mathrm{~m}$ $\mathrm{dbh}$, and their tops could be clearly seen only from opposite valley sides. A small proportion exhibited signs of decadence, mostly top dieback, but by far the majority had $>60 \%$ crown and looked fine. Could it really be that those ancients many more than 1000 years old - have suddenly become unhealthy en masse over the last 30 years? Examination of disks from large diameter old-growth trees invariably reveals that their annual increments are not always strong. Narrow annual rings, sometimes several decades lasting, are interspersed with periods of faster growth, indicating that lean growth periods were not uncommon. But, the trees did not fall down! They endured the stress, and then they continued growing and contributing to forest habitat. Are our few remaining giants really in trouble, or merely enduring a lean period? Arguments for clearcutting old growth stands frequently have no scientific credibility whatsoever, in terms of either the current health status or the potential longevity of the trees. What are lacking, for purposes of justifying old growth harvesting, are reliable physiologically based indicators of tree-health status. We expect it in medicine; why not in forestry?

On the other side of the country, in New Brunswick, the provincial government allows trees down to $12.5 \mathrm{~cm}$ diameter (stump height) to be harvested as a step toward ensuring continuing sustainability - obviously not of forest health no, sustainability of mill quotas in view of an impending wood shortage. Three centuries ago, New Brunswick and the surrounding regions were blessed with giant eastern white pines, some of the best mature red pine stands in the country, ancient eastern white cedars, and beautiful stands of mixed-aged tolerant hardwoods - oaks, ashes, beeches, maples, yellow birch, chestnut, hickory, butternut, etc. - as well as with the spruce-firjackpine pulpwood species now everywhere planted. The white pine, red pine, cedar and tolerant hardwoods have not been replaced. New Brunswick is now reduced to condoning the harvest of small juvenile wood, rather than allowing our forests to reach maturity, much less ripe old age. Unemployment and economic under development are problems that must be addressed; thus, the mills must be kept operational, and the international demands created by an exponentially soaring world population must be capitalized upon. But, how sad to think that the land will probably never again realize its potential, in terms of producing old growth forests.

\section{Production Forests and Vatwood}

In New Zealand, radiata pine trees have been grown at less than $1 \times 1$ metre spacing for short-rotation pulp or sawlog production. Those stands are like swards of grass. Having previously been selected as superior for height growth, the trees do reach impressive heights $10 \mathrm{~m}$ or more - in their first decade. The tight spacing discourages branch growth, minimizes stem taper, and leads to photosynthate and nutrients being allocated mainly to extension. Not even a child can begin to squeeze through such stands, and with early canopy closure there is virtually no understorey. The trees grow well in concert, and extensive lower branch dieback and natural delimbing occur. Therefore, the operational harvesting 
efficiency exceeds that of less dense stands. In the future, as tree improvement efforts are supplemented by the work of genetic engineers, and as monocultures tend toward monoclonal cultures, productivity of such intensively managed stands will certainly increase.

Are not such fibre farms also what industry in Canada would like to have, what it really needs to keep the pulp mills burping, folks employed, and the economy strong? For the forester who is a naturalist at heart, such production forests may be repulsive, but when pulpwood fibre is the only real objective, when industry is footing the bill, and when politicians know maintenance of low unemployment is the best way to get re-elected, the naturalist viewpoint hardly matters. Our field and office "production" foresters can undoubtedly handle fibre farms.

But why stop there? In my laboratory, and a number of others around the world, methods have been developd to obtain fibres reliably from in vitro cultures of cambium or other plant tissues, independently of the tree. Fibre differentiation can be induced at will, and the fibre:fine ratios achieved in those cultures are much higher than those generated within tree stems. Although technology transfer has not yet occurred in the case of in vitro fibre production, it certainly has for somatic embryogenesis and other in vitro methods.

The writing is on the wall. The only real question remaining concerns whether the costs in support of vatwood production will be more than offset by the savings to the pulpwood industry for not having to produce nursery stock, plant, tend, protect, harvest, truck and pulp trees. Thus, a day can be foreseen when pulping of wood chips will be looked back upon as a primative technology, replaced by processing of uniformly consistent high quality free-floating fibres produced in huge industrial vats under controlled conditions. Using such advanced technology, even non-forestry nations will be able to become self-sufficient in pulp and paper and various kinds of re-constituted wood production.

Such a technologically innovative day will be the logical culmination to the prevailing short term-economics mentality. It will free an enormous area of land land unsuitable for agriculture, unde-

\section{PROFESSIONAL DIRECTORY DIRECTOIRE PROFESSIONNEL}

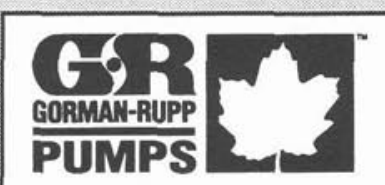

\section{Canadian \\ Manufacturers \\ of Municipal and \\ Forestry Fire Pumps}

Gorman-Rupp of Canada Limited

70 Burwell Road, St. Thomas, Ont.

Tel. (519) 631-2870 Fax (519) 631-4624

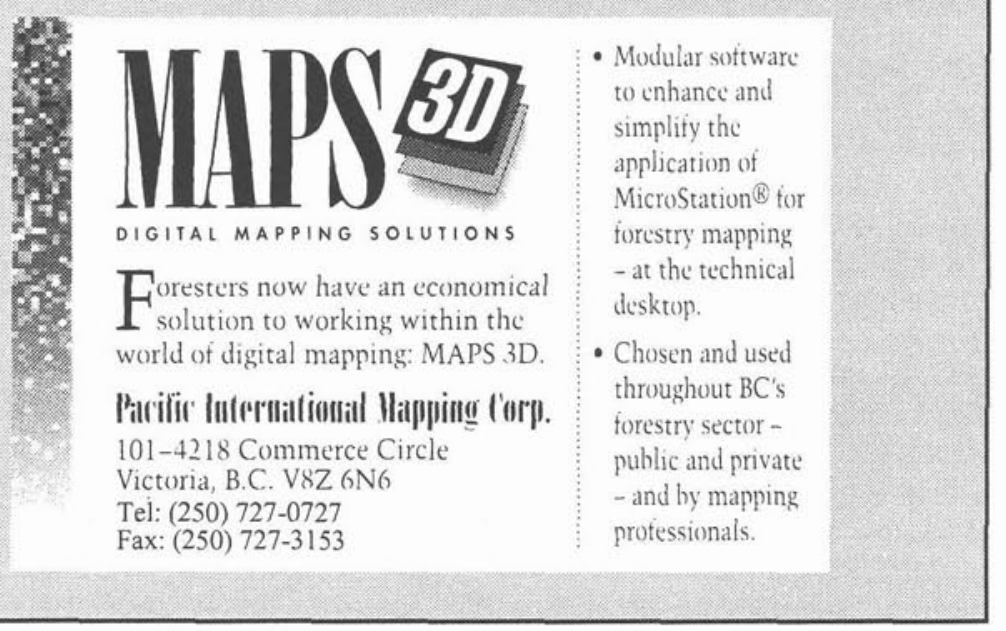

sired for urbanization, and currently used almost exclusively for pulpwood production - for mature forestry purposes. The magnificent old growth forests which once were so prevalent in Canada may just possibly be renewed for future generations.

\section{A Healthy Forest Contains Healthy Trees}

Healthy trees are the base ingredient for producing healthy forests. There are important ecological roles fulfilled by snags, aged unhealthy trees, and fallen logs existing - here and there - in otherwise healthy forests. Thus, an area having $100 \%$ healthy trees would be unnatural, but this does not preclude having tree health as the foremost management objective. Physiologists have no shortage of management tools available for inducing healthy trees to die or become more or less rapidly unhealthy (it's easy to break something, not so easy to put it back together). One of the important research challenges for forestry, in terms of simulating Mother Nature's ability to produce healthy forests, is to understand which tree species to manipulate where (in time and space) to achieve desired outcomes.

A healthy tree is more than merely a productive tree. A healthy tree is, first and foremost, a healthy living system in its own right, oblivious to human economy and the values we may place on the tissues and chemical substances of which it is composed. In like manner to a healthy human, a healthy tree might be considered a living system able to perform those physiological functions for which it was genetically programmed, exactly in the manner in which it is programmed. Sure, it is able to acquire light, water, $\mathrm{CO}_{2}$, $\mathrm{O}_{2}$, and inorganic nutrients in order to build a physically and chemically complex structure. That is the productivity side. More importantly, it is able to metabolize in ways which enable it to survive for hundreds, even thousands, of years, and also to reproduce. A major difference between a tree and a human (or other ambulatory organism) is that when the environment becomes unsatisfactory, the mobile organism is able to seek better living conditions, whereas the perennial woody plant must remain stationary and endure, or succumb to, changing physical, chemical and biological factors. Thus, the ecological niche occupied by the tree or other perennial plant is much more constraining than that occupied by most animals, or even by annual or biennial plants. Consequently, although there 
undoubtedly are other useful indicators of forest health, the best indicator is the health of its individual trees. By managing for healthy trees at every stage in their lives, healthy populations and forests will be sustained and, environment permitting, productivity will also be sustained.

Physiological stresses are the reality of Canadian forestry. Few of the processes generating such stresses are subject to management intervention, in terms of either practicable feasibility or cost. Xylem-limited bacteria, foliar endophytes, herbivor or insect debudding and defoliating, physical damage from wind, ice and snow, limiting soil moisture or nutrients, low light, temperature extremes - these are all normal, to be encountered virtually everywhere in Canadian forests. In response to a severe stress, even the healthiest tree will be physiologically shocked and, consequently, exhibit a reduction or cessation of growth for a time, but that response of itself does not mean the tree is a write off. As can be readily seen in the annual rings of old growth, the tree may have the intrinsic ability to endure and recover from such stress.

The trees encountered by early Canadians had proven themselves worthy of their environment. To achieve healthy forests in the future, our trees must be sufficiently healthy to stand alone and ensure the major environmental extremes that have long characterized Canada - the severe once-only-everyone-hundred-years physical, chemical or biological change that tests their fitness to reside in this region of earth - and survive self-reliantly. There should be no compromising on this point.

The fact is, however, that we have already compromised. "Creaming" and clear-cutting have removed our healthiest trees. These productivity methods were sanctioned hand-in-hand with a "renewable resource" mentality which imagined even better stock would be growing in our future forests. However, no one yet knows for sure what cost, in terms of tree health or longevity, has attended the small gains in growth rate and other genetic changes achieved in our tree improvement programmes. Certainly, fast-growing trees are predisposed to produce abnormal wood, an indication that their healthiness may have been compromised by selection pressures focussed on productivity.

My hopes are that our current forestry management practices are not sustainable,

\section{TORONTO}

\section{Recent Research Contributions}

US Patent Granted to Dr. T.J. Blake and K.D. Vishnevetskaia, entitled "Method for reducing transpiration in plants". It was discovered that the antioxidant Ambiol (a hydroxybenzimidazole derivative) increases growth and drought tolerance of a number of agricultural and forestry species. Seed treatment with the appropriate concentration of this antioxidant increased water use efficiency (more carbon absorbed per unit of water transpired) by limiting plant transpiration under stress.

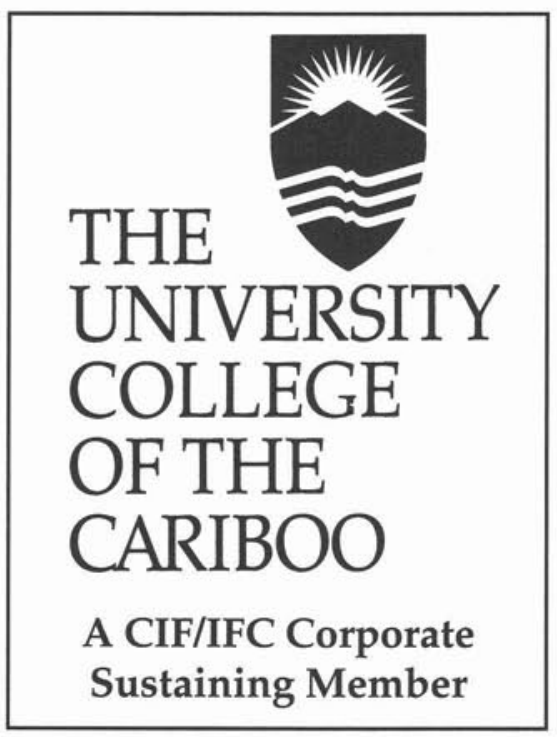

that the good of the forest will be put before the pride of the profession, and that the need to emphasize forest health will be recognized and become the paramount concern of forestry. Happily, the Canadian Forestry Service recently initiated a "Forest Health" S\&T network (CFS 1997), and the BC Ministry of Forests has noted that "Forest health is... an important consideration in forest practices..." (Muir 1997).

CFS. 1997. Canadian Forest Service Science and Technology Networks, Overview. Atlantic Forestry Centre, Fredericton, NB.

Muir, J. A., editor. 1997. Forest health progress, May 1997. BC Ministry of Forests, Forest Practices Branch, Victoria, BC.

\section{Faculty Briefs}

At the end of August 1997, the first group of Master of Forest Conservation (MFC) programme's students completed their internships. A key component of the programme, the internship is an intensive practical summer placement of 2-3 months' duration with industries and agencies working on actual forest management problems. Students worked with a variety of "hosts" to gain practical training and fieldwork. Feedback from both hosts and students seems to indicate that the internships were a great success. Host organizations for this year included: Environment Canada; Halifax Regional Municipality; Ministry of Natural Resources; Lake Abitibi Model Forest; Forest Stewardship Council; Society for Promotion of Wastelands Development (India); Union de Permisionarios - Union de Conservacion y Desarrollo Forestal \#4 (Mexico). The graduation date for the 1997 MFC class is December 1997.

The second group of MFC students entered the programme at the end of August starting with a 10-day field camp in cooperation with Dr. Peter Schleifenbaum from the Haliburton Forest and Wildlife Reserve Limited. As well, two students from the Faculty of Forestry at the Agricultural University of Vienna (BOKU) participated in the MFC field camp.

On 18 September, a one-day meeting was held at the Faculty of Forestry to establish an "Ontario Node" composed of representatives from industry, universities, and government to coordinate research on Sustainable Forest Management in Ontario in association with the Network of Centres of Excellence funded by the federal government through the Natural Sciences and Engineering Research Council of Canada. As a result of this meeting, a small working committee consisting of Dr. Vic Timmer, Faculty of Forestry, University of Toronto, Dr. Rob Farmer, Faculty of Forestry, Lakehead University, and Mr. Martin Litchfield, E.B. Eddy Forest Product Ltd., has been established to carry the initiative forward. The workshop was attended by approximately 30 people from a wide range of forestry sectors.

Dr. Lada Rajasekaran is currently working with Professor Terry J. Blake on the development of new natural plant growth regulators and compounds extracted from conifer seeds. Compounds have been isolated that accelerate growth and drought tolerance when reapplied to 
conifer seed. Their role in preventing seedling senescence is being studied.

\section{Papers Presented}

Kant, S. 1997. Community forest management: An optimal resource regime for sustainable forest management. Presented at the annual meeting of the Canadian Association of Forest Economists at Rimousiki, Quebec, 10-12 September 1997.

\section{Papers Published}

Kant, S. 1997. Integration of biodiversity of conservation in tropical forest and economic development of local communities. Journal of Sustainable Forestry. 4(1/2): 33-61.

Kant, S. and Anke Redantz. 1997. An econometric model of tropical deforestation. Journal of Forest Economics. 3(1): 1-36.

Kant, S. and J. C. Nautiyal. 1997. Production structure, factor substitution, technical change, and total factor productivity in the Canadian logging industry. Canadian Journal of Forest Research. 27(5): 701-710.

Gustavo, R. Braier, J. C. Nautiyal, and S. Kant. 1997. Identification of the economically efficient sources of wood for a large pulp mill in Argentina. INFOR. 35(1): 15-36.

Blake, T. J., Sperry, J., Tschaplinski, T. J. and Wang, S. S. 1996. Water relations. In: Biology of Populus and its implication for management and conservation. Chapter 16 Edited by R. F. Stettler, H. D. Bradshaw, P. E. Heileman \& T. M. Hinckley. NRC Press, National Research Council of Canada. Ottawa, ON. pp. 401-422.

Darlington, A., Vishnevetskaia, K. D. and T. J. Blake. 1996. Growth enhancement and antitranspirant activity following seed treatment with a derivative of 5-hydroxybenzimidazole (Ambiol) in four drought-stressed agricultural species. Physiologia Plantarum 97: 217-222.

Fan, S. and T. J. Blake. 1997. Comparison of polyethylene glycol 3350 induced osmotic stress and soil drying for drought simulation in three woody Species. Trees: 11: 342-348.

Darlington, A. B., Halinski, A., Dat, J. F. and T. J. Blake. Effects of increasing saturation pressure deficit on growth and ABA levels in black spruce and jack pine. Trees: 11: 223-228.

\section{Meetings}

\section{FEBRUARY 1998}

- AGM, Alberta Forest Technologists Annual General Meeting, 21 February. Edmonton, Alberta. Contact: Alberta Forest Technologists Assn, 5320-122 Street, Edmonton, Alberta. Tel. (403) 432-1962, Fax. (403) 432-7046, E-mail: dlind@agt.net.

\section{MARCH 1998}

-50th Annual Meeting, Association of BC Professional Foresters, 4-6 March.

Victoria, BC. Contact: Chris Lee, Chair, Organizing Committee, Canadian Forest Service, 506 West Burnside Road, Victoria, BC. V8Z 1M5. Tel. (250) 363-0792, Fax. (250) 363-0775 E-mail: clee@a1.pfc.forestry.ca.

- Eleventh Annual British Columbia Forest Industry Conference, 10 March. Vancouver, BC. Contact: Pat Buchanan, Price Waterhouse, 601 West Hastings Street, Vancouver, BC V6B 5A5. Tel. (604) 682-4711, Fax. (604) 662-5312.

- World of Wood'98, 10-13 March. Coronado, California. Contact: The International Wood Products Association, 4214 King Street, West, Alexqandria, Virginia 22302, USA. Fax. (703) 820-8550.

\section{- Complex Diseases of Forest Trees,} 16-21 March.

Vienna, Austria. Contact: Thomas Cech, Tel. 43-1-87838-147 Fax. 43-1-8775907.

- North American Conference on Pesticide Spray Drift Management, 29 March-l April.

Portland, Maine. Contact: Tammy Gould, Tel. (207) 287-7593, Fax. (207) 287-7548, E-mail: attgoul@state.me.us.

\section{APRIL 1998}

- Micropropogation and Spread of Genetically Superior Material of Forest Trees, 10-13 April.

New Delhi, India. Contact: P.K. Khosla, Dr. Y.S. Parmar, University of Horticulture \& Forestry, PO Nauni, Solan 173230 HP India. Tel. 91-1792-52288, Fax. 91-1792-52242, 20225, E-mail: dext@yspuhf.ren.nic.in.

\section{- Hydrology, Water Resources, and Ecology in Headwaters, 20-23} April.

Merano, Italy. Contact: European Academy, Weggensteinstrasse 12/A, I-39100 Bozen/ Bolzano, Italy. Tel. 39-471-306111, Fax. 39-471-306099, E-mail: headwater98@ ms.sinfo.interbusiness.it.
MAY 1998

- FAO/IUFRO Joint Symposium on the management of Mountain Watershed, 4-8 May

Marienbad, Czech Republic. Contact: Albert Güttle, Bayrisches Staatsministerium fur Landesentwicklung und Umweltfragen, Franz Josef Strauss-Ring 4, D-8000 Munchen 22, Germany. Fax. 49-89-92144302.

- Second Annual Alberta Forest Industry Conference, 14 May.

Edmonton, Alberta. Contact: Sandra hildegrand, Price Waterhouse, 1501 Toronto Dominion Tower, Edmonton, Alberta T5J $2 Z 1$. Tel. (403) 420-2477, Fax. (403) 493-8272.

- Hazard Mapping in Torrent Watershed, 11-14 May.

Salzburg, Austria. Contact: Gernot Fiebiger or Erich Scheuringer, Forest technical Service in Torrent \& Avalanche Control, District Salzburg \& Halein, Paracelsusstrasse 4, 5027 Salzburg, Austria. Tel. 43-662-878152, Fax. 43-662-870215

\section{- History and Forest Resources,} 18-23 May.

Florence, Italy. Contact: Dr. Mauro Agnoletti, Istituto di Assestamento e Technolgia Forestale, Universita di Firenze, Via San Bonaventura 13, 50145 Firenze, Italy. Tel: 39-55-3023140, Fax: 39-55-319179, E-mail: agnoletti@ cesit1.unifi.it.

- Third International Symposium on Spatial Accuracy. Assessment in natural resources and environment, 20-22 May.

Quebec City, Canada. Contact: Kim Lowell, Tel. (418) 656-5491, Fax. (418) 656-3607, E-mail: spatial.accuracy@scg.ulaval.ca.

- Forest and Water, 25-29 May. Cracow, Poland. Contact: Piotr Kowalik, Politechnical University of Gdansk, Faculty of Environmental Engineering, PL-80952. E-mail: pkow@pg.gda.pl.

- International Symposium on Corrosion in the Pulp and Paper Industry, 26-29 May.

Ottawa, ON Canada. Contact: Mr. Robert Wood, Technical Section, CPPA, 1155 Metcalfe St., 19th Floor, Montreal, QC, Canada H3B 4T6. Tel. (514) 866-6621, Fax. (514) 866-3035, E-mail: rwood@cppa.ca.

- Seventh International Syposium on Society and Resource Management, 27-31 May.

Columbia, Missouri. Contact: Dr. Sandy Rikoon, University of Missouri-Columbia, 